\title{
From Colony to Special Administrative Region: Issues of Hong Kong's Autonomy within a Centralized Authoritarianistic State ${ }^{1}$
}

\author{
By Anthony B.L. Cheung
}

\section{Introduction}

One of the key tests of Hong Kong's viability as a Special Administrative Region (SAR) of the People's Republic of China (PRC) is whether the city will be able to maintain a high degree of autonomy as guaranteed by the 1984 Sino-British Joint Declaration ${ }^{2}$. However, the notion of 'autonomy' is something which is not easy to definite beyond contentions in legal or constitutional terms. Indeed, both the Joint Declaration and the Basic Law of the Hong Kong Special Administrative Region ${ }^{3}$ have only referred to a 'high degree of autonomy'. In other words, there exists a spectrum of degrees of autonomy.

The actual degree of autonomy which Hong Kong enjoyed as a dependent territory of the United Kingdom (UK) during more recent years of colonial rule was not really reflected by its colonial status whereby the British Government could govern it with absolute will. The reality is: since the post-War years, the Hong Kong colonial administration had been able to secure a relatively high degree of autonomy in domestic affairs from the home government in London (fiscal autonomy since the 1950s and independence from UK in trade relations since the 1970s), although matters of defence and foreign affairs remained to be firmly within the hands of the latter. Hence relations with the PRC Government had been handled through the Foreign \& Commonwealth Office's seconded Political Adviser. The post-1997 future of Hong Kong was negotiated between the UK and PRC Governments during 1982-84. After 1984, as Hong Kong began to move on its constitutional journey towards self-administration, it would have been reasonable for more autonomy to be granted to the territory and its locally-constituted representative institutions in line with the

Revised text of a paper presented at the International Conference on 'Constitutional Transition: Hong Kong 1997 and Global Perspectives', organized by the Faculty of Law, University of Hong Kong, Hong Kong during 29 May - 1 June 1997.

2

Joint Declaration of the Government of the United Kingdom of Great Britain and Northern Ireland and the Government of the People's Republic of China on the Question of Hong Kong, September 1984, Hong Kong: Government Printer.

Promulgated by the PRC National People's Congress on 4 April 1990 as the mini-constitution for the Hong Kong Special Administrative Region to take effect on 1 July 1997 when Hong Kong reverts to Chinese sovereignty. 
spirit of 'Hong Kong people governing Hong Kong'. However, the politics of the transition had produced a scenario whereby the Sino-British Joint Liaison Group ${ }^{4}$ which, though not exercising the authority of a condominium, had become a major centre of negotiation and decision-making between the two sovereign governments on major policies affecting Hong Kong's governance, such as electoral reforms and the building of the new international airport.

From 1 July 1997 onwards, Hong Kong in principle has become an SAR with a high degree of autonomy and can decide for itself in any matters outside the province of national defence and foreign affairs. Yet there is still great concern about undue mainland Chinese intervention in Hong Kong's domestic affairs, so much so that President Jiang Zhemin has to exhort mainland officials to fully abide by the Basic Law ${ }^{5}$ and ex-Director Lu Ping of the State Council's Hong Kong \& Macau Affairs Office had to tell mainland ministries, departments and organizations in mid-1996 "not to extend their hands to Hong Kong"6

\section{Hong Kong's autonomy as SAR within the PRC's present constitutional configuration}

\section{Compared with autonomous regions of national minorities in PRC}

As far as the PRC Government was concerned, autonomy for the Hong Kong SAR was premised not so much on constitutional considerations as on political ones. Indeed the PRC constitution as last amended in 1982 contains only one article on the SAR, i.e. Article 31 in which it is provided that the State when necessary can set up Special Administration Regions the system of which shall be prescribed by the National People's Congress (NPC) in law according to the specific circumstances. The brevity of the constitutional provision for the SAR contrasts strongly with the more detailed prescriptions for self-autonomy enjoyed by national minorities regions set out in Chapter 6 of the Constitution (altogether

4

5

President Jiang Zhemin in his speech at the ceremony marking the establishment of the Hong Kong SAR on 1 July 1997, made it clear that "... No central department or locality may or will be allowed to interfere in the affairs which, under the Basic Law, should be administered by the Hong Kong Special Administrative Region on its own" (page 4 of the officially translated English text).

6

Lu Ping, during a visit to Japan in May 1996, reportedly warned various Central Government ministries and commissions as well as provincial and local authorities not to extend their hands to interfere in the affairs of Hong Kong. He repeated the message at a joint meeting held in July 1996 by the Communist Party Central Propaganda Department, the Army General Political Department and other central agencies on the Hong Kong question, emphasizing that central departments are not allowed to give direct instructions to the SAR and not to set up offices in Hong Kong within permission. See Hong Kong Economic Times, 3 July 1996 (in Chinese). 
11 articles). It can be argued purely from a legal point of view that there is more constitutional safeguard for the autonomy of national minorities regions than for that of the SAR. The notion of regional autonomy for the national minorities as contained in the PRC Constitution gives such minorities regions some limited initiative powers in relation to local matters such as language, education, health and culture, and in organizing their own public security forces. It is grounded in the macro-policy need to respect the minorities' own cultural traditions, customs and religion, so much so that they can adopt practices that may deviate from what national policies require. Such autonomy is different from a clear division of powers and responsibilities between the centre and the regional tiers as implied in a devolved state structure such as a federal system. A very important factor which still restricts the amount of autonomy that the minorities regions can achieve in practice is economic: these regions depend quite heavily on financial and personnel assistance from the Central Government. Without economic and fiscal powers, autonomy is more nominal than real.

In terms of the systems to be adopted in the SAR, there is clearly a greater degree of autonomy (or separation) from the dominant mainland system of state socialism. The PRC Government policy towards Hong Kong after 1997, as promulgated through the SinoBritish Joint Declaration, allows Hong Kong to have its own social, economic and judicial systems. Hong Kong has its own court of final appeal, a separate judicial jurisdiction, a separate customs jurisdiction, and a separate currency. Hong Kong also continues to enjoy fiscal autonomy and the power to conduct its own trade relations. Under Article 151 of the Basic Law the SAR may on its own, using the name of 'Hong Kong, China', maintain and develop relations and conclude and implement agreements with foreign states and regions and relevant international organizations in the economic, trade, financial and monetary, shipping, communications, tourism, culture and sports fields. There are in principle no other vertical relationships of leadership over SAR government departments, public authorities and other social organizations by their mainland central counterparts as those existing between central organs and provincial/region organs in the PRC constitutional configuration - the so-called "tiao tiao kuai kuai" arrangements. Hence, for example, the Hong Kong Monetary Authority as Hong Kong's central bank is not subordinate to the People's Bank of China; neither is the SAR civil aviation authority subordinate to the Central Civil Aviation Authority. The SAR legislature, unlike provincial/region people's congresses, is not subject to the direction and leadership of the National People's Congress. To that extent, the substantive autonomy to be enjoyed by Hong Kong as an SAR created under Article 31 of the PRC Constitution is greater than that provided for autonomous minorities regions. 
Hong Kong is also to be more 'special' and autonomous than Special Economic Zones (SEZs) in the mainland like Shenzhen, Zhuhai and Xiamen. As Chinese leaders are quick to point out, the SEZs are special zones of the socialist sector of the PRC whereas Hong Kong is to remain capitalist. Thus there are things Hong Kong can do which the rest of the PRC, no matter how special or how open the economy is, cannot do. Hong Kong is special not only in terms of its economy, not also in terms of its political and legal systems. Hence Hong Kong laws and not mainland PRC laws (with the exception of those national laws explicitly applied to the SAR through Article 18 of the Basic Law) are applicable in the SAR. It can be said that entirely different sets of legal doctrines, standards and practices exist between the mainland and Hong Kong, one based on the socialist Chinese system and the other on the English common law system. Tensions may, however, occur when both systems have to legislate against and deal with common offences such as subversion, upsetting 'national security', etc.

In general, if compared with the rest of PRC which is still governed by a Communist Partycontrolled state under the principle of democratic centralism ${ }^{7}$, the Hong Kong SAR can certainly be regarded as a very autonomous part of China.

\section{Hong Kong's autonomy compared to the British colonial past}

The next question is whether Hong Kong under PRC sovereignty after 1 July 1997 has become more autonomous that it did under British rule before 1 July. In this regard, one would notice that both the Sino-British Joint Declaration and the Basic Law have retained essentially the same set of central-local power relationships between Hong Kong and the sovereign government as existing in the British colonial era. Existing autonomies, such as in fiscal, trade and certain external relations matters, are to be maintained. Hong Kong's financial surplus need not be handed over to the Central Government ${ }^{8}$. Neither will the latter levy any national taxes in Hong Kong ${ }^{9}$. The centre, however, will also retain some veto powers as previously available to the British sovereign. 


\section{Power of executive appointment}

In terms of executive appointments, the Central Government will continue to appoint both the Chief Executive (CE) and his principal officials, even though the $\mathrm{CE}$ is to be elected locally by a selection committee. Chinese leaders have always emphasised that the power to appoint the $\mathrm{CE}$ is a substantive one, not a nominal one. Indeed, under Article 43 of the Basic Law, the CE is to have dual accountability: accountable to both the Central People's Government and the SAR.

\section{Power to veto local legislation and to extend national laws}

Analogous to the British Crown's power of disallowance of colonial legislation ${ }^{10}$, all SAR bills, after being passed by the Legislative Council and given assent by the $\mathrm{CE}$, need to be reported to the National People's Congress Standing Committee for record under Article 17 of the Basic Law. The NPC Standing Committee has the power to declare any such SAR laws null and void should they be considered not in conformity with the provisions of the Basic Law regarding affairs within the responsibility of the Central Authorities or regarding the relationship between the Central Authorities and the SAR.

Similar to be application of UK Acts of Parliament to Hong Kong as a British Colony, Article 18 of the Basic Law provides for the extension of PRC national laws to the SAR. In addition, the Article provides that

"in the event that the Standing Committee of the National People's Congress decides to declare a state of war, or by reason of turmoil within the Hong Kong Special Administrative Region which endangers national unity or security and is beyond the control of the government of the Region, decides that the Region is in a state of emergency, the Central People's Government may issue an order applying the relevant national laws in the Region."

The relevant national laws to be applied to the SAR in the event of a state of emergency will presumably include the laws relating to the imposition of martial law.

Article 23 of the Basic Law further requires the SAR to enact laws to prohibit any act of treason, secession, sedition, subversion against the Central People's Government, or theft of state secrets, to prohibit foreign political organizations from conducting political activities in the SAR, and to prohibit political organizations of the SAR from establishing ties with foreign political organizations. References to 'subversion' and 'foreign political organizations' were added in the aftermath of the June 4 Tiananmen crackdown in 1989 when Bei-

10

Article VIII of the Letters Patent to the Governor of Hong Kong. 
jing became highly sensitive about Hong Kong being turned into a so-called counterrevolutionary base of subversion ${ }^{11}$.

\section{Military control}

Furthermore, the People's Liberation Army garrison stationed in the SAR after the departure of the British garrison carries the same symbolic significance of sovereign power over the territory. Unlike the previous arrangements whereby the British Governor acted concurrently as Commander-in-Chief of British troops in Hong Kong, the PLA garrison answers only to the Central Military Commission in Beijing and the CE does not have command over the deployment of the garrison. In addition offences, whether criminal or civil, committed by members of the PLA Garrison in the course of duty are not justiciable by SAR courts ${ }^{12}$.

\section{Judician'}

Although the Hong Kong SAR enjoys judicial autonomy with final adjudication, the judiciary's jurisdiction does not extend to acts of state such as defence and foreign affairs. This is in line with common law practice in the British system. However, unlike in common law where the court decides if a matter belongs to an act of state, under Article 19 of the Basic Law it is for the CE and the Central People's Government to decide on questions of fact relating to acts of state. In a ruling of the court of appeal of the High Court in July 1997, the three High Court judges took the opinion that the status of the Provincial Legislative Council. whose legality was challenged by democrats and many in the legal community, was outside the jurisdiction of the SAR court because the decision to set up this provincial body was made by the central sovereign authorities. By so doing the SAR courts have taken their own steps to delimit local judicial jurisdiction.

11 Article 23 of the Draft Basic Law published by the Standing Committee of the PRC National People's Congress in February 1989 for extensive consultation in Hong Kong and in other parts of China, simply stated: "The Hong Kong Special Administrative Region shall enact laws on its own to prohibit any act of treason, secession, sedition or theft of state secrets".

12

Articles 21 and 23 of the Hong Kong Special Administrative Region Garrison Law, enacted by the Standing Committee of the National People's Congress on 30 December 1996 and extended to the

13 SAR on 1 July 1997 under Article 18 of the Basic Law.

South China Morning Post, Hong Kong, 30 July 1997. 


\section{Transition of Hong Kong's autonomy from British rule to PRC sovereignty: same intentions, different contexts}

\section{Notions of autonomy}

It is therefore quite clear that the kind of autonomy which the PRC Government has envisaged for the HKSAR is premised on practices of 'autonomy' that Hong Kong already enjoyed as a British colony in the 1980s when the Sino-British Joint Declaration was signed. This is a manifestation of China's 'no change' policy for Hong Kong under 'One Country Two Systems' for 50 years. The constitutional details worked out for the SAR in the Basic Law arose simply from the need of political expediency to reassure various social and economic elites in Hong Kong as well as the civil service (which would become a key pillar of governance after the end of colonial rule) that no substantive change to the Hong Kong system would occur after China's takeover. There had never been any forwardlooking blueprint and entrenchment for Hong Kong's autonomy within the overall constitutional framework of the PRC which remains to be couched in the political doctrines of democratic centralism - meaning that much power still rests with the Central Authorities dominated by the Chinese Communist Party. The PRC has never contemplated relaxing central political control over provincial/region/local tiers of government in China, despite economic and fiscal decentralization in the past decade. Federalism or some kind of confederation has never been on PRC's agenda. The proposed reunification of Taiwan with the mainland is still articulated within the 'One Country Two Systems' formula now adopted for Hong Kong and Macau. For Tibet, where there is considerable pressure of separatism, the SAR approach is not even proposed as a viable option by Beijing although the exiled Dalai Lama was in the past willing to accept an arrangement similar to Hong Kong's as a means to solve the longstanding conflict with the Central Government.

A formula premised on political expediency would mean that the policy could be applied with suitable flexibility and moderation even though the constitutional provisions may have given the Central Government much residual powers. In a state system as the PRC where the leaders' views weigh more than any constitutional doctrines or legal provisions, such flexibility may create uncertainties and indeterminacy. During the 1980s when the Basic Law drafting process was underway, there were arguments by some Hong Kong drafters such as democrats Martin Lee and Szeto Wah that the SAR should enjoy a different kind of residual power, namely that any powers outside the spheres of national defence and foreign affairs should rest with Hong Kong. Such a notion was categorically rejected by Beijing which insisted on a residual power regime whereby unless expressly devolved to Hong Kong, responsibilities (and powers) would continue to rest with the Central Government as the sovereign. Hence the Basic Law as a constitutional document has essentially retained a Central Government-SAR relationship where the centre has much veto power over the SAR (in appointment, legislation, adjudication over 'acts of state', emergency laws etc.). 
If the Central Government is to actively and extensively make use of the powers reserved to it in the Basic Law, then the amount of autonomy available to the SAR could turn out to be quite limited. This is of course similar to Hong Kong's previous situation as a British colony. However, since the 1970s, the British Government had increasingly ceased to exercise active administration of Hong Kong, leaving matters of day-to-day government and policymaking to the senior civil service and those business and professional elites coopted into the administration through appointment to advisory boards and committees. The question is: will Beijing follow London's precedent in terms of the passive use of its reserved sovereign powers.

\section{Hong Kong's different relations with Beijing compared to London as the sovereign}

Ultimately it depends on how committed Chinese leaders are in terms of honouring the promises of a high degree of autonomy to Hong Kong as contained in the Sino-British Joint Declaration. As at now few will doubt the good intentions of senior leaders like Jiang Zemin and Qian Qichen, but there are still concerns as to whether in practice what is intended can be fully implemented. Two considerations are in order here. First, there is a fundamental difference between Hong Kong's relations with London and with Beijing that of geographical distance. As an overseas outpost far away from the British Isles, Hong Kong under British rule by the late 20th century was already quite different from Hong Kong before the Second World War when Britain was still keen on maintaining a global imperial empire. By the 1980s Hong Kong, other than representing an outstanding historical problem inherited from the Opium War with Imperial China in 1840, was no longer an important issue on Britain's national agenda. Indeed the new generation of political leaders in London are increasingly looking towards Europe as the final destiny of their country. There is no longer any desire in empire building or in keeping overseas colonies. On the other hand, Hong Kong had been increasingly leading its own life as part of the AsiaPacific region and had little interest in the sovereign state. There was limited political mutual interest between Hong Kong and UK and thus limited incentive for UK to interfere with and control Hong Kong.

As part of the PRC, however, Hong Kong is now very much integral to the overall social, economic and political development of China. Hong Kong's economy is increasingly integrated with that of mainland China and has indeed become the key locomotive of growth in southern China. The PRC has every incentive to ensure that Hong Kong develops in a way it wants and to play those roles which Beijing has set in mind for the AR under its overall modernization strategy for China. Hong Kong will become a very important bargaining chip for the PRC in negotiations with the US, Japan and other trading nations, such as in terms of air landing rights. Hong Kong has already proved to be significant to Beijing in the latter's negotiations with Taiwan as evidenced in the talks on shipping 
arrangements i May 1997. There is no reason to believe that Hong Kong will be left alone by Beijing as by London in the final years of colonial rule. In addition, after the 'overreaction' of Hong Kong people about the 1989 crackdown on pro-democracy activities in mainland China, Beijing has always been wary of the territory's potential as a base for subversion of the mainland political system. Hence Beijing's repeated exhortations that Hong Kong's 'well water should not interfere with [mainland China's] river water', and that Hong Kong should remain an economic city and not a political one which can be manipulated by international forces unfriendly to the PRC. This policy is in line with Deng Xiaoping's 1987 ruling that should Hong Kong be turned into a base of opposition to the mainland in the name of 'democracy', then "We have but to interfere" ${ }^{14}$. Thus Hong Kong's geographical proximity to mainland China means it is not easy for it to be free of Beijing's direct control or influence in practical terms and it is not easy for Beijing to turn a blind eye to developments in Hong Kong lest these would lead to undesirable consequences. It was precisely with such concerns in mind that in late 1989 Beijing decided to strengthen provisions for emergency laws in Article 18 of the Basic Law and to require the SAR to legislate against subversion and links with foreign political organizations in Article 23.

The second concern has to do with what avenues of redress there are should the Central Government in Beijing unduly intervene in the affairs of the SAR. Some commentators had in the past pointed to the British Parliament, which is elected and operates in a democratic manner, as a main source of protection of rights in Hong Kong even though the territory was in constitutional terms just a dependent colony. After return to the PRC, where the National People's Congress is only one of the state organs doing the bidding of the Chinese Communist Party which leads the government and where there is no real separation of powers or check and balance, Hong Kong cannot expect to find any particular institutional mechanism which can dispense it with constitutional justice should the need for it arise. In a system where the will of the state is supreme and where the state is taken to mean the executive authority controlled by the Party, the National People's Congress, its Standing Committee or even the courts are likely to rule in favour of the Central Authorities if there is any dispute over jurisdiction or division of powers between the former and the SAR.

The Basic Law provides for a Basic Law Committee to be established under the National People's Congress Standing Committee. This Committee, comprising 6 members each from the mainland and Hong Kong, advises the NPC and NPC Standing Committee on matters relating to the interpretation of the Basic Law (Article 158), ruling if local legislation is in conformity with the Basic Law (Article 17), and the application of PRC national laws to Hong Kong in addition to those already listed in Annex III of the Basic Law (Article 18). However, the Committee is not judicial in nature even though its membership includes 
people from the legal profession ${ }^{15}$. It will be more a political mechanism whereby centrallocal constitutional and political disputes can be discussed and mutually resolved. The outcome of any such dispute-resolution is bound to be shaped by political power dynamics and not just by rational debate or legal doctrines.

\section{Legalist vs political approach to safeguard autonomy}

By now it is clear that it is not in line with present realities to expect Hong Kong's autonomy to be defined and safeguarded simply by legal and constitutional stipulations, as those in what can be described as the 'legalist school' were advocating in the $1980 \mathrm{~s}^{16}$. Given Hong Kong's longstanding tradition of the rule of law, it is conceivable that more legal provisions would mean greater guarantee. However, within the terms of the centrallocal relations, it would be difficult to argue for taking away all reserved powers of Beijing as the Central Government in which the national sovereignty resides. And given that the Basic Law has to be operated within the PRC constitutional framework as a piece of PRC national law, it is equally difficult to argue against the NPC having the final decision in the interpretation of Basic Law provisions. To go for a narrow legalist paradigm to define and protect regional autonomy will still leave Hong Kong very much exposed to the uncertainties of the surrounding political environment that really constitutes the source of the autonomy problem.

The contrasting approach is to focus more on politics, working on securing maximum space for political manoeuvre in the mainland-Hong Kong interface - the so-called 'political school' approach. This would entail, for some, cultivating better relations with mainland leaders and organizations, not challenging the centre's supremacy, and enabling the centre to build up its trust in the $\mathrm{SAR}^{17}$. If the Central Government is reassured, so the theory goes, it will feel less inclined to interfere with the SAR. Advocates of this school would argue that instead of pushing Beijing on detailed guarantees in the small print, attention should be devoted to just the broad principles which would contain sufficient flexibilities to accommodate diverse circumstances. The tradition of the Chinese Communist leadership has been that policies are usually very broadly and vaguely defined so that they could cover virtually anything that can be done to meet the strategies or even tactical needs of the times. A good example is the policy of economic reform and opening up. Much of the 'revolution'

Like Prof essor Albert Chen, Dean of the Faculty of Law at the University of Hong Kong, and Ms Maria Tam, lawyer and ex-Basic Law Drafting Committee Member.

An example is the attempt by Martin Lee and Szeto Wah to argue for residual powers to rest with Hong Kong rather than the Central Govemment in the earlier drafting process of the Basic Law.

17

The approach being adopted by Chief Executive Tung Chee-hwa reflects such a political way of dealing with the Central Government. 
which has taken place in China during the past two decades in what some people have described as a move towards capitalism was accommodated within the broad notion of 'socialism with Chinese characteristics'. According to a similar logic, so long as the top leaders are satisfied, anything can be allowed in the SAR in the name of 'One Country Two Systems'. What is permissible is politically determined rather than legally or constitutionally determined given that the PRC polity is still centred around leaders instead of institutions. Hence Hong Kong should work for minimum constitutional rigidities and maximum political interaction. To some critics, pursuing such a political approach might imply 'kowtowing' to Beijing. Such critics would argue for Hong Kong standing firm in face of any undue intrusion by Central Authorities into the city's domestic governance. In terms of political interaction, the strategy can thus be to create either 'love' or 'fear' for the centre 'love' so that the centre does not feel the need to interfere, and 'fear' so that the centre does not dare to interfere too much because the price of doing so is too high. In practice, a more viable strategy should be a mixture of the two.

At this stage it is premature to tell which of the two approaches will bring about a better pay-off. Probably both the legalist and political strategies are just two sides of the same coin of autonomy. Without any legal safeguards, Hong Kong will be at the mercy of political expediency. Without sufficient economic and political weight to back it up, autonomy on the law book is superficial.

\section{Prospect of autonomy for Hong Kong Special Administrative Region: Constraints and Possibilities}

The practice and operationalities of SAR autonomy in Hong Kong after 1 July 1997 will be affected and shaped by a range of factors incorporating the wills and desires of both mainland authorities and the local population. The scenario is expected to be highly interactive and not susceptible to simple delineation one way or the other. Certain perimeters can be identified which are premised on constitutional, historical, institutional and realpolitical considerations.

\section{Constitutional safeguards}

Despite the limitations of constitutional provisions within the Basic Law as explained above, and the subservience of the law to politics in the PRC constitutional framework, the safeguards for autonomy in the Basic Law are still important, particularly as these safeguards are rooted in and thus reinforced by the 1984 Sino-British Joint Declaration which is an international agreement registered with the United Nations. The PRC has always prided itself of abiding by all its international agreements and commitments. More recently 
the Chinese leadership, led by President Jiang Zhemin, has been advocating 'governing the nation by law' ${ }^{18}$. It is thus inconceivable that Beijing would easily break its own words unless there are grave political crises forcing it to do so. Any deviation from legally stipulated arrangements and safeguards will exact a great political price from the PRC Government. Such act will also cost the PRC its integrity and honour in the eyes of the international community. As the present Chinese leadership is trying hard to strengthen the PRC's global profile and status as a great nation ${ }^{19}$, it goes against Beijing's rational interest to renege on what it has promised to Hong Kong in the Sino-British Joint Declaration and the Basic Law.

\section{Historical and sociological consideration}

While Chinese officials used to praise Deng Xiaoping's 'One Country Two Systems' concept as a great scientific innovation to deal with the reunification of divided nations, the fact remains that Deng's formula is more an art than a science. It is an art because it offers an opportunity for the PRC to take back Hong Kong without imposing its socialist system on the territory which can still thrive in its deviant capitalist way - a kind of 'historical compromise' that separates dignity (of national sovereignty) from dogma (of ideological unity). Historically Hong Kong had always been operating in a One Country Two Systems mode with British rule providing some kind of buffer between the mainland system and the Hong Kong system, and giving Beijing the excuse of not reuniting Hong Kong with the motherland but still insisting that Hong Kong people were Chinese compatriots who happened to live under an alien administration resulting from a historical question which would be resolved when the ripe moment came.

The promise of 'One Country Two Systems' and a policy of no change for 50 years therefore represent an undertaking to continue with history in a reinvented context - with PRC replacing $\mathrm{UK}$ as the sovereign and the PRC installing a new SAR construct to provide a different kind of buffer between two separate systems. Chinese leaders know too well that the Chinese population in Hong Kong resent the socialist system on the mainland, which is the reason why so many people have escaped or migrated to the British colony in the past several decades since 1949 and why the mainstream opinion in Hong Kong at the beginning of Sino-British talks in the early 1980s was in favour of some form of British presence

See Jiang's report to the 15th Congress of the Chinese Communist Party, 12 September 1997, Beijing. He stated in Part 6 of his report that there is a need to expand socialist democracy, to improve socialist legal system, to govern the nation according to the law and to construct a socialist legally-governed state.

19

As witnessed, for example, by Jiang Zhemin's high-profile maiden visit to the USA to meet President Clinton in November 1997. 
in exchange for the transfer of sovereignty. This 'people' factor is probably the strongest sociological disincentive for Beijing to backtrack from its promise of high autonomy and self-administration for Hong Kong. The people factor will also mean that after 1 July 1997 the local population will keep suspicious eyes on the words and deeds of mainland officials and authorities and will not swallow any undue intrusion without protest. With the development of representative politics in Hong Kong, elected politicians and their political parties, in particular opposition forces such as the Democratic Party, will perform the role of gatekeeper on uninvited interventions. They will also make sure that the Chief Executive and his SAR Government do not 'kow-tow' to mainland authorities on issues of vital interest to Hong Kong. Some form of localism is bound to develop in the SAR.

\section{Institutional factors}

Local institutional factors in favour of autonomy also include the civil service which has already become almost an independent institution under British rule on the eve of the transfer of sovereignty. The British Hong Kong civil service has more or less automatically become the civil service of the SAR. It is not part of, and indeed alien to, the state cadre system in mainland China. While senior civil servants, who are used to their domination of administrative and policymaking powers in the colonial configuration of governance, are not keen to have their powers shared or checked by newly-emerging local political parties, they would resent interventions by mainland cadres even more strongly. They are expected to work on the Chief Executive so as to turn him into a bulwark against mainland intrusions and to make sure he would not become simply an obedient agent of the Central Government.

As far as the mainland institutions are concerned, there is not reason to assume that all mainland authorities and organizations will share the same agenda on the SAR. While officials in the Central ministries, such as the Foreign Affairs Ministry and the Hong Kong \& Macau Affairs Office, took a hardline on the British Government on issues of political reforms during Hong Kong's transition, they are also known to be sufficiently sensitive to international reaction and the need to maintain a balanced approach to various rival interests in Hong Kong. There exist well-known clashes between Beijing officials and cadres based in Hong Kong on how to conduct the struggle against the British and other opposition elements, with the former advocating relatively more moderate approaches. Provincial and municipal governments in the PRC may take a different view on Hong Kong from the Central Government. Some of them, like Guangdong and Shenzhen, may share the same interest as the Hong Kong SAR in terms of getting greater autonomy from and less direct control by the centre. They may have areas of competition with Hong Kong, but they may also sympathize with the latter when matters of regional interest versus central control arise. They may want to extend their hands to the SAR too, and in this regard they would 
find that the centre will play the role of guarantor and protector of the SAR. So the 'mainland' institutions are not as monolithic in interest and behaviour as some may take them to be on the surface.

\section{Realpolitical considerations}

For the PRC Hong Kong's return in 1997 is not just a way to get rid of an historical shame for the Chinese nation, thus to solve a longstanding historical problem. Hong Kong represents a significant strategic move for the PRC. Allowing Hong Kong to maintain its present system and to thrive as an active economic and financial centre internationally will enhance the PRC's opening up policy and secure for it an important outlet to the outside world (to be the 'window' of China, as Deng Xiaoping used to describe Hong Kong]. Keeping some kind of 'barrier' between Hong King and the mainland through the operation of the twosystems arrangements will enable some foreign governments to continue with granting Hong Kong separate policy treatment as they did in the days of British rule otherwise the SAR would have to be dealt with in the same stringent terms as assigned to the PRC. A good case in point is the USA adopting the Hong Kong Policy Act in 1993 so as to provide a separate policy status for Hong Kong and its residents. In order to maintain international confidence in Hong Kong and its future viability as an autonomous part of the PRC, Beijing has the incentive to be more tolerant of Hong Kong's autonomy and deviance from mainland 'socialist' systems. This consideration forms an important realpolitical foundation to the 'One Country Two Systems' concept as part of PRC's global strategy.

The other strategic consideration relates to using the Hong Kong SAR as a showcase for reunification to the people of Taiwan. Although both Taiwan's Government and the majority of its population do not seem to warm to the Hong Kong SAR formula as an attractive approach to reunification and would prefer a kind of 'One Country Two Governments' alternative, it is still imperative in whatever circumstances for Beijing to demonstrate its commitment to respecting autonomy for Hong Kong after 1997 otherwise any hope of reunification with Taiwan by peaceful negotiation would evaporate. A military option, though possible in theory, will be undesirable in terms of both national Chinese sentiments and international reaction.

Therefore, for the national interests of Taiwan reunification and international confidence, the PRC Government has no good reason to unduly subdue Hong Kong. However, whether good intentions can be translated into good implementation has always been a problem in contemporary Chinese government. In this regard, one should take note of recent developments in PRC central-locality relations. 
The conventional understanding of central-locality relations has been premised on a dominant centre dictating its policy wills to the provincialities. Although the literature did not deny the existence of so-called 'parochial' provincial interests, those were often portrayed as the personal interests for political advancement and sometime physical survival (e.g. during the Cultural Revolution) or provincial leaders' perceptions of the interest of the province. More recent studies on reform implementation, as pointed out by $\mathrm{Li}^{20}$, have shown centreprovince relations to be less lopsided than assumed in what is now considered to be a 'f ragmented authoritarianism' model of mainland Chinese politics. Under the revised model, instead of viewing power dynamics in the PRC as a top-down domination, there is increasing ground for interpreting them within essentially an interactive relationship, in which both the centre and the locality can 'win' in a non-zero-sum power game. Successive decentralizations since the late 1970s during the new reform era have also meant that there are now less resources available to the centre to secure locality subservience. Party-political or administrative coercion is insufficient to override the provinces. The latter have now increased bargaining power and they would not be reluctant to demand more concessions from the centre in exchange for respecting the latter's nominal supremacy.

Within this evolving picture of the PRC's centralized authoritarianistic regime, it is conceivable that the autonomy of the Hong Kong SAR will not thus be a static notion, but will be subsumed and further evolve within the broader megatrends of change in China. Hong Kong has to learn from the experience of its provincial/municipality counterparts on the mainland the tactics of bargaining and negotiation with the centre. Autonomy or subordination is not going to be pre-determined by constitutional design or the macropolitical relations in any simplistic manner. Afterall, autonomy in practice is to be achieved and shaped on the ground, at the micro-level of day-to-day interaction.

Linda Chelan $\mathrm{Li}$, Towards a Non-zero-sum Interactive Framework of Spatial Politics: the Case of Centre-Province in Contemporary China, Political Studies, Vol. XLV, No. 1, March 1997, pp. $49-$ 65 . 


\title{
ABSTRACTS
}

\section{The Community of the Portuguese Speaking Countries (2)}

\author{
By Paulo Canelas de Castro
}

On July 17, 1996 the Community of Portuguese Speaking Countries (Comunidade dos Paises de Língua Portugesa - CPLP) was created as an association of seven States, not characterized by a regional coherence, but primarily by a language and a "regionalism of identity". The first part of the article, published in VERFASSUNG UND RECHT IN ÜBERSEE, no. 2 (1998), p. 122-150, surveyed the constituent treaty, especially regarding the institutions provided and their functioning. It also focussed on the objectives of the international organization in multilateral diplomacy, internal cooperation and promotion and diffusion of the Portuguese language and its orientating principles. Finally, the author compared the CPLP structures to the British Commonwealth from a political and legal perspective.

This second part of the article deals with the emerging identity of the CPLP, the status of the individual within the CPLP on the road to citizenship, the position of the CPLP in global international relations and international law and, finally, with perspectives of an own human rights policy.

\section{From Colony to Special Administrative Region: Issues of Hong Kong's Autonomy within a Centralized Authoritarianistic State}

\section{By Anthony, B.L. Cheung}

Since Hong Kong from 1 July 1997 onwards has become an SAR of the People's Republic of China one of the key tests of Hong Kong's viability is whether the city will be able to maintain the high degree of autonomy as guaranteed by the 1984 Sino-British Joint Declaration. The article focusses on the details of this autonomy within the PRC's present constitutional configuration compared to the British colonial past and analyses some concerns referring to special aspects of the transition from British rule to PRC's sovereignty. The author comes to the conclusion, that Hong Kong will have to learn from the experience of its provincial/municipality counterparts on the mainland the tactics of bargaining and negotiation with the centre, for autonomy in practice "... is to be achieved and shaped on the ground, at the micro-level of day-to-day interaction". 